\title{
Editorial: Information literacy and lifelong learning
}

\author{
John Crawford
}

\section{Introduction}

The term, information literacy, which means the use, evaluation and repurposing of information for a wide range of uses was coined by Paul Zurkowski (1974) and drew its initial inspiration from the American publishing industry. A key major developmental policy document was the American Library Association's Presidential Committee on information literacy: final report (American Library Association, 1989) which emphasised the importance of information literacy, not only in formal education, but also in the workplace, lifelong learning and as a civil and civic right and that, as a concept, it extended well beyond the education sector.

However, in the 1990s and the early 21 st century, interest in and promotion of information literacy was located mainly in higher education where it was linked to independent learning and innovative learning and teaching strategies. Rader (2002) found that $60 \%$ of publications concerning information literacy covering the last three decades of the 20th century concentrated on academic libraries and (Harding 2008) reported that less than 2\% of the literature on information literacy had any focus on public libraries. This despite the fact that it was pointed out as long ago as 1997 that "the information needs of consumers or the general public have been wholly neglected by information researchers" (Nicholas and Marden 1997, 5) and Partridge et al. (2008, 110) have pointed out that little research has been conducted which explores information literacy within the context of everyday life.

More recently attention has focused on non-academic environments: the workplace, personal health management, skills development and the increasing role of the public library as a centre for the promotion of information literacy skills to a wider public.

Two key documents of the early 21st century are the Prague Declaration (UNESCO 2003) and the Alexandria Proclamation (Garner 2005) which identify information literacy as both a civil right and skills right.

\section{Author}

Dr John Crawford is Chair of Information Skills for a 21st Century Scotland and a member of the Library and Information Research Editorial Board.

Email: polbae2003@yahoo.co.uk 
A more recent focus on the workplace and informal learning has led to the redefinition of what an information source is and emphasises the social and collaborative nature of the process. Information literacy has a key role in the skills development agenda and in combating social deprivation and disadvantage which moves it a long way from the earlier view of information literacy, deriving mainly from higher education, which saw information literacy skills development as primarily an individual activity focusing around print and online sources. To understand information literacy today we have to include not only the evaluation and use of traditional "library" sources but also social policy issues, relating to the relief of inequality and disadvantage, skills development for a post-industrial society, critical thinking and lifelong learning, an activity which information literacy informs and supports. There is also the issue of digital literacy, school and higher education curricula, early years learning, health issues, the dynamics of the workplace and learning and teaching skills and strategies which place an increasing emphasis on teaching and learning in informal situations. A key figure in this process of redefinition is Annemaree Lloyd (2010) who has reconceptualised information literacy as a collaborative and social activity, dependent on personal and communal relationships and less linked to the conventional repertoire of online and print sources.

It is undoubtedly the case that the use of academic and pedagogic jargon is offputting to those from non-academic backgrounds as Shiva Darbandi and colleagues have pointed out in their article and jargon has even attracted wry comment from within the higher education sector. Godwin $(2012,19)$ has remarked on "the portentous language used in the name of scholarship to make it appear appropriately impressive".

\section{Papers}

It is against this background that the idea for this special issue was conceived. This is not the first journal special issue on information literacy "outside the academy" which I have guest-edited. I have guest-edited two special issues of the American academic journal, Library Trends on the theme of "information literacy beyond the academy" (Library Trends, 2012a; 2012b) the first of which was concerned mainly with information literacy policy issues while the second dealt with organisational issues, theoretical perspectives and practical issues. The call for papers successfully attracted leading contributors from all over the world.

The aim of this special issue is a little more modest. It aims to bring together both research articles and reports on the theme of information literacy in a lifelong learning context. It is hoped that they will be useful to information professionals working in this area, who may find the reports helpful in reviewing and planning their own activities and who may find the research articles useful in contextualising and conceptualising their work. It was anticipated that the bulk of the contributions would come from within the UK which has turned out to be the case but there are also important articles from the Republic of Ireland and the United States. There are eight articles in total including four reports, two of which are on public libraries while a third, on the Welsh Information Literacy Project, has some material on public libraries. There follows four research articles, three of 
which are peer reviewed. The workplace and skills development issues are key themes both for librarians and the wider community.

In 'The learning continuum: economical best practices for implementing and achieving a community's information literacy goals', Shiva Darbandi and colleagues report on a pilot study in which Credo and Lancashire Library Service went into partnership to develop information literacy training for both library staff and their users. They review the problems of promoting information literacy in a non-academic environment where there is no element of compulsion and training must be provided which is relevant and engaging. Training for paraprofessional staff was achieved by online webinars. This was followed up by training for the general public and although attendances were initially small, numbers have grown over time. Multimedia materials have been produced including videos explaining what the library's resources are and how they can be used.

In the 'Welsh Information Literacy Project', Dr Andrew Eynon reports on the third phase of the highly successful Welsh Information Literacy Project, now in its third year. Phase three focuses on schools and public libraries. This includes the appointment of information literacy champions in schools and public libraries. Five public library services are running pilot projects on developing information literacy skills for their staff and two are delivering information literacy skills to their users. Presentations have been given to senior teachers in various parts of Wales. Contact has also been made with departments of education to highlight the importance of information literacy to student teachers. 'Dundee College's literacy information skills project' is a report by Abigail Mawhirt which although located in the Further Education sector has relevance outside formal education. She explains how library staff work with students with learning difficulties and use information literacy skills training to improve the students' self-confidence and learning skills generally. It is significant that the students found the library a more supportive learning environment than those they had encountered before.

In the last of the four reports 'IT learning sessions at Leeds Library and Information Service', Jason Tutin describes the IT and information literacy skills training provided by Leeds Library and Information Service, which is flexible and user-driven and offers both non-accredited and accredited training. A special feature of this article is the discussion about qualifications which library staff have obtained to make them more confident teachers. It is important for public library staff to co-operate with other relevant organisations like Job Centre Plus and Jason explains how this is done in Leeds.

In the first research article 'BILI: building information literacy in Ireland', Amy Connolly and her colleagues report on a study on how to develop information literacy policy and practice in the Republic of Ireland. Its results derive from data collected from 26 information literacy experts including seven from outside Ireland. There are two principal recommendations. The first recommendation suggests setting up a high level advocacy committee, composed of leading figures within the profession in Ireland (high level strategists and managers). Advocacy should take place both within the profession and to the wider community. Secondly, a practitioner-led community of practice, composed of innovative practitioners, who manage and implement information literacy programmes 
throughout Irish libraries is also proposed. Not surprisingly, the training of librarians especially in teaching skills is mentioned.

In 'Information literacy in adult returners to Higher Education: student experiences in a university pre-entry course in a UK university', Anthony Anderson and colleagues discuss the information usage problems that adult returner students encounter when returning to study. The authors present the issue very much as a lifelong learning one rather than just a higher education problem. They report on the outcomes of interviews with 18 students ranging in age from over 21 to 70. Distrust of the Internet emerged among interviewees and textbooks were viewed as a more reliable source. Information literacy skills or the lack of them were found to be linked to a wider understanding or lack of understanding of how the students understand knowledge itself. Not surprisingly the need for information skills training emerged as an issue.

The last two articles take up the theme of information usage in the workplace. In 'What information competencies matter in today's workplace?' Alison Head and colleagues, in a well-documented study, investigate the extent to which recent graduates in the workplace (new hires) can use the information literacy skills they have learned at university. The findings are based on interviews with 23 US employers and focus groups with 33 recent graduates from four US colleges and universities. The new graduates in their first jobs found the transition from college to the workplace daunting. They had to meet unrelenting deadlines but were challenged by vaguely defined workplace research tasks and received little feedback on their performance. The use of offline sources and working with others was little understood as the 'new hires' had mostly worked on individual assignments at university, usually with direction from a lecturer. The need to reconfigure information skills training in higher education to make it more relevant to the workplace situation is a key finding.

Finally, in 'iKnow: information skills for a 21 st Century workplace', Katharine Reedy and colleagues report on a joint initiative by the Open University Library Service and the Centre for Outcomes Based Education to develop training materials for the workplace. Information skills training packages for higher education are very common but unusual in the workplace. The package is based on a review of the literature, interviews and focus groups. A generic learning package was developed which generated variable feedback, a notable finding being the need to avoid academic jargon and to place more emphasis on people as sources of information and the role of informal and social learning. It was found difficult to engage with small to medium sized enterprises (SMEs), an important finding, which has been replicated elsewhere. Given that SMEs are the most important component of the economy and are probably much in need of information literacy skills this is a serious matter.

From these eight articles several general points emerge. Public libraries are now beginning to develop learning materials but in the same rather piecemeal manner which characterised universities in the past. However, in a public library context librarians can usefully work with other informal learning contributors such as Community Learning and Development staff (Crawford and Irving 2012). Appropriate qualifications and suitable training for librarians outside higher 
education are also important issues, as Jason Tutin shows, but it is also important to maintain an informal non-threatening learning atmosphere, as shown by the example of Dundee College. Ten years ago McNicol and Dalton (2003) found that there is a conflict between offering tentative learners a comfortable learning environment and the possibility that formal evaluation may put these learners off, changing an informal relaxed atmosphere by introducing formal connotations.

As Alison Head and colleagues and Katharine Reedy and her colleagues show the workplace presents the most intractable problem of all with considerable information skills needs being clearly demonstrated but no effective overarching strategies for addressing them. Librarians seem slow to adopt the language of the corporate environment, still preferring the rhetoric of higher education and seem to have no answer to the information problems of the SME.

Anthony Anderson and colleagues link information literacy skills with the more general understanding of knowledge and the processes of thought which characterise lifelong learners in using information, and which need to be better understood by librarians who ought to be aware that people in non-formalised environments outside education may not even be aware that they are engaging in information literacy activity (Birdsong and Freitas 2011, 589).

\section{References}

American Library Association (1989) Presidential Committee on information literacy: final report. Chicago: ALA. URL:

http://www.ala.org/ala/mgrps/divs/acrl/publications/whitepapers/presidential.cfm [accessed 20.04.13].

Birdsong, L. and Freitas, J. (2011) Helping the non-scholar scholar: information literacy for life-long learners, Library Trends, 60(3), 588-610.

Crawford, J. and Irving, C. (2009) Information literacy in the workplace: a qualitative exploratory study, Journal of Librarianship and Information Science 41(1), 29-38. URL: http://lis.sagepub.com/cgi/content/abstract/41/1/29?etoc [accessed 13.03.13].

Garner, S.D. (2005) High-level colloquium on information literacy and lifelong learning [online] URL: http://www.ifla.org/publications/high-level-colloquiumon-information-literacy-and-lifelong-learning [accessed 17.04.13].

Godwin, P. (2012) Information literacy and Library 2.0: an update. In: Godwin, P. and Parker, J. (eds.) Information literacy beyond Library 2.0. London: Facet. 1926.

Harding, J. N. (2008) Information literacy and the public library: we've talked the talk but are we walking the walk? Australian Library Journal, 57(3), 274-294. URL: http://www.alia.org.au/publishing/alj/57/ALJ_Vol57_No3_2008.pdf [accessed 05.05.13].

Library Trends (2012a). 60(2).

Library Trends (2012b). 60(3). 
Lloyd, A. (2010) Information literacy landscapes. Oxford: Chandos.

McNicol, S. and Dalton, P. (2003) Public libraries: supporting the learning process. Centre for Information Research, University of Central England, Birmingham. URL:

http://www.ebase.bcu.ac.uk/docs/public_libraries_learning_report.doc [accessed 05.05.13].

Nicholas, D. and Marden, M. (1997) The information needs of parents, Aslib Proceedings, 49(1), 5-7.

Partridge, H, Bruce, C. and Tilley, C. (2008) Community information literacy: developing an Australian research agenda, Libri, 58(2), 110-122. URL: http://www.librijournal.org/pdf/2008-2pp110-122.pdf [accessed 05.05.13].

Rader, H. B. (2002) Information literacy 1973-2002: a selected literature review, Library Trends, 51(2), 242-259.

UNESCO (2003) The Prague Declaration: towards an information literate society. Prague: UNESCO. URL:

http://portal.unesco.org/ci/en/files/19636/11228863531PragueDeclaration.pdf/Pra gueDeclaration.pdf [accessed 17.04.13].

Zurkowski, P. (1974) The information environment: relationships and priorities. Washington DC: National Commission on Libraries and Information Science.

\section{Open access and copyright}

Library and Information Research is an open access journal. A freely available copy of this paper may be downloaded from the journal's website:

http://www.cilipjournals.org.uk/lir

Copyright and associated moral rights in works published in Library and Information Research are retained by the author(s) but this paper may be used freely, with proper attribution, in educational and other non-commercial settings. 